\title{
Comportamiento de hormigones de alta resistencia reforzados con fibras de acero frente al impacto de proyectiles
}

\section{Behavior of steel fiber high strength concrete under impact of projectiles}

\author{
M. F. Cánovas ${ }^{(*)}$, V. M. Hernando(*)
}

Recepción/Received: 28-II-11

Aceptación/Accepted: 01-VII-11

Publicado online/Online publishing: 04-VI-12

\section{RESUMEN}

Este trabajo presenta los resultados de la investigación llevada a cabo por los autores sobre el comportamiento de hormigón de $80 \mathrm{MPa}$ de resistencia característica a compresión reforzado con diferentes cuantías de fibras de acero de alto contenido en carbono sometido al impacto de proyectiles de distintos calibres, determinando el espesor de muros de este tipo de hormigón que sería preciso disponer para impedir su perforación por dichos proyectiles, así como los valores máximos de penetración, para que en el caso de no producirse perforación y solo penetración, no se genere cráter, "scabbing", en el trasdós de los mismos. Previamente a los ensayos balísticos fue preciso diseñar los hormigones para que presentaran determinadas características mecánicas, especialmente las relacionadas con la ductilidad, dado que estos hormigones especiales deben absorber la elevada energía que le transmiten los proyectiles y las ondas de choque que los acompañan.

Palabras clave: hormigones de alta resistencia, fibras de acero, blindajes, perforación de proyectiles, "scabbing".

\section{SUMMARY}

This paper presents the results of the investigation carried out by the authors about the behavior of $80 \mathrm{MPa}$ characteristic compression strength concrete reinforced with different amount of high carbon content steel fiber, submit to impact of different caliber projectiles, determining the thickness of this type of concrete walls needs to prevent no perforation, as well as the maximum penetration to reach into them, so that in the event of no perforation and only penetration, "scabbing" phenomena does not take place on the rear surface of the wall. Prior to ballistic testing was necessary to design the highstrength concrete with specific mechanical properties, especially those related to ductility, since these special concrete must absorb the high energy of projectiles and also the shock waves that accompany them.

Keywords: high strength concrete, steel fibers, shields, piercing projectiles, scabbing.

(*) Universidad Politécnica de Madrid (Madrid, España). 


\section{INTRODUCCIÓN}

En recintos de edificios destinados a comunicaciones, centros informáticos de gran responsabilidad, centros responsables de la defensa y seguridad nacional, etc., es importante proteger sus cerramientos frente a determinadas amenazas, especialmente procedentes de acciones terroristas. Estos cerramientos deben presentar un grado de blindaje acorde con el tipo de amenaza y la probabilidad de la misma. El hormigón se presenta por sus características mecánicas, facilidad de moldeo y bajo coste, como un material adecuado, de aquí el gran uso que se ha realizado a lo largo de los años, para aprovechar su carácter protector frente al impacto de proyectiles y explosiones (1).

Las investigaciones realizadas sobre impacto de proyectiles en hormigón no son recientes, existiendo una amplia bibliografía en la que aparecen fórmulas empíricas de penetración de proyectiles en hormigón que se han ido perfeccionado a lo largo de los años y que han sido fruto de aproximaciones estadísticas a alguna curva tipo de un conjunto de datos obtenidos como resultado de ensayo de disparos de proyectiles de distintos materiales, formas, y calibres, sobre blancos de hormigón (2-5). La evolución de los proyectiles ha cambiado de una forma muy rápida $y$, aunque en menor grado lo haya hecho el hormigón, no por eso ha dejado de experimentar importantes mejoras, con lo cual muchas de las fórmulas empíricas existentes de penetración han quedado obsoletas dando valores por defecto cuando se aplican con los proyectiles modernos y con los hormigones especiales actuales.

El espesor del blanco y las características mecánicas del mismo poseen una importancia notable en el proceso de frenado de un proyectil. Los blancos pueden clasificarse en delgados y masivos. Estos últimos, como son los de hormigón, se caracterizan por poseer un espesor igual o superior a diez veces el calibre o diámetro del proyectil. En los blancos delgados, de menor espesor que el calibre, normalmente metálicos o de materiales compuestos, la disipación de la energía del proyectil se realiza principalmente por deformación plástica y generación de calor en un área más o menos grande del blanco, siendo fundamental la tenacidad y ductilidad del mismo. Dado el reducido espesor de los blancos delgados, la estabilidad giroscópica y trayectoria del proyectil apenas si experimentan variación; no ocurre lo mismo en los blancos masivos en los que se produce una pérdida de energía cinética por generación de calor en régimen adiabático e irreversible que afecta a la estabilidad giroscópica e, incluso, a la trayectoria del proyectil.

Conocer la trayectoria de un proyectil y cómo cambia su velocidad dentro de un blanco es importante para determinar el espesor a dar a los blindajes, a fin de impedir que aquel los atraviese o que, aunque no llegue

\section{INTRODUCTION}

At sites hosting communications centres, information technology (IT) centres, and security and national defence buildings, among others, it is important to protect walls and roofs against certain threats, in particular terrorism, and provide them with such protection according to the type and probability of the threat. Concrete, due to its mechanical properties, easy moulding and low cost, and given its sound protective nature against the impact of projectiles and explosions, is a suitable material for such application and has been used extensively over the years (1).

Research into the impact of projectiles is not recent, with there being an extensive literature which shows how empirical penetration formulae have been refined over the years as a result of statistical approaches to representative curve data sets obtained through tests involving projectiles of different materials, profiles and sizes, on concrete targets (2-5). The development of these projectiles has changed swiftly, meaning that many empirical penetration formulae are now obsolete (given that they provide default values when applied to modern projectiles and the special concretes in contemporary use).

The thickness and mechanical properties of the target are of notable importance in the projectile braking process. Hence, these targets can be classified as either thin or massive. The latter, such as concrete ones, are classified by having a thickness of not greater than 10 times the calibre or projectile diameter. In the case of thin targets, which are of a lesser thickness than the projectile calibre and are typically made of metallic and composite materials, dissipation of projectile energy is through plastic deformation and heat generation in an area slightly larger than the target, with the toughness and ductility of the target being essential. Given the lesser thickness of thin target, the gyroscopic stability and trajectory of the projectile experience hardly any variation. Contrarily, this does not arise in massive targets, where a loss of kinetic energy occurs due to the generation of heat, in adiabatic and irreversible processes, that affects gyroscopic stability and even projectile trajectory.

Acquisition of knowledge about the trajectory of a projectile, and how its velocity changes within a target, is important when determining the thickness to be given to it in order to prevent the projectile from passing 
a hacerlo, se produzcan proyecciones de fragmentos que puedan ser peligrosos para el personal o equipos delicados (informáticos, comunicaciones, etc.).

Cuando un proyectil incide y penetra en un blanco (en el caso estudiado de hormigón), dependiendo de su masa, velocidad de incidencia, ductilidad y características geométricas, puede que lo perfore y lo abandone por su trasdós a una menor velocidad, o bien que no llegue a producirse la perforación y el proyectil quede frenado dentro del blanco penetrando hasta una profundidad determinada. Tanto si se produce la perforación como si no, al llegar el proyectil a una distancia determinada del trasdós, denominada "profundidad límite de scabbing", se producirá un cráter de salida ("scabbing") y una proyección de fragmentos de hormigón a gran velocidad. Este fenómeno, que se produce antes de que el proyectil haya alcanzado la cara posterior del blanco, es atribuido a las ondas de Rayleigh y a la reflexión de las ondas de choque en dicha cara; la onda reflejada pasa a ser de tracción fracturando y lanzando fragmentos de hormigón a gran velocidad desde la misma.

La penetración de un proyectil en un blanco, como es el hormigón, se produce siguiendo un mecanismo complejo. El proyectil en su vuelo libre posee una velocidad mayor que las ondas de presión generadas por su movimiento, de tal forma que el efecto de estas inicia la fragmentación del hormigón cuando el proyectil incide en el blanco. La energía cinética que lleva el proyectil se trasfiere al hormigón disipándose en energía de compresión radial que desde la punta del mismo va comprimiendo y desplazando al hormigón para abrirse paso, y en energía calorífica provocada por la fricción del proyectil contra el material del blanco dando lugar a una elevación de temperatura importante en el entorno del mismo y, muy especialmente, en su punta, en un tiempo muy reducido, de tal forma que el fenómeno puede considerarse como adiabático repercutiendo muy negativamente en la resistencia del blanco. Previamente a la acción propia de perforación del proyectil el frente de onda avanza a una velocidad muy superior a la de éste de forma que la energía trasferida es suficiente para fracturar al hormigón antes que aquel inicie su efecto de perforación.

En el punto de incidencia del proyectil con el blanco se produce un cráter de entrada de poca profundidad en comparación con la del cráter de salida, generado por las ondas de presión superficiales (ondas de Rayleigh), denominado "spalling".

El estudio de los fenómenos que se producen en la penetración de un proyectil en un blanco masivo como es el hormigón, como se ha indicado, es complejo pues dentro del blanco el proyectil tiene que abrirse camino through or, should it not do so, to prevent the fragments that could endanger personnel or damage sensitive equipment (such as communications equipment and IT hardware, amongst others).

When a projectile strikes and penetrates a target (in the case studied here, one of concrete), depending on its mass, impact velocity, ductility and geometric characteristics, it can perforate and leave the target via its rear surface at a slower velocity, or perhaps not perforate it with the projectile being subject to a braking process and penetrating only to a certain depth. Whether perforation occurs or not, upon reaching a given depth (termed the "scabbing limit") an exit crater will be produced (termed "scabbing") and a projection of highvelocity fragments of concrete. This phenomenon, which occurs prior to the projectile reaching the rear surface of the target, is an attribute of Rayleigh waves and the reflection of shock waves on this rear surface. The reflected wave becomes a traction wave that breaks and releases high-velocity fragments of concrete.

The penetration by a projectile of a target, such as the case of concrete, is produced in accordance with a complex mechanism. As a projectile travels in free flight its velocity is in excess of that of the pressure waves generated by its movement, which means that the effect of this initiates fragmentation of the concrete when the projectile strikes the target. The kinetic energy carried by the projectile is transferred to the concrete, with it being dissipated in radial energy that from the tip compresses and displaces the concrete. The calorific energy generated by the friction of the projectile with the material of the target in turn leads to a significant rise in temperature, not only in the immediate environment but also, and particularly, at the tip. Given that this occurs in a short duration of time, the phenomenon could be considered as adiabatic and one that undermines the strength of the target. Prior to the penetration action performed by the projectile, the wave front advances at a velocity significantly higher than the projectile, which in turn shows that the energy transferred is of a sufficient degree to fracture the concrete before the effect of perforation is initiated.

At the point of impact of the projectile with the target, an entrance crater (though of little depth if compared with the exit crater) is generated by surface pressure waves (Rayleigh waves), termed as "spalling".

The study of phenomena that occur in the penetration by a projectile of a massive target such as concrete is complex, given that in the inner parts of the target the projectile needs to open a path for the warhead to create 
para lo cual la ojiva de éste crea esfuerzos de compresión muy fuertes en un hormigón que está fragmentado por la onda de presión y además a alta temperatura; aparte de esto, hay un efecto de fricción muy fuerte con el cuerpo del proyectil que hace que exista una pérdida creciente de su energía cinética, con lo cual este termina frenado dentro del blanco, o bien, si no es así, produciéndose la perforación, saliendo el proyectil por su cara posterior con menor velocidad. Cuando el proyectil es teóricamente indeformable, como ocurre con los que hemos empleado en este trabajo, que son de núcleo duro, se elimina uno de los factores que hacen complejo el estudio teórico de la penetración que es la deformación de éste y la pérdida de la forma puntiaguda de su cabeza. En el proceso de absorción de energía por el blanco juega un papel importante la forma del proyectil y sus características mecánicas, especialmente tenacidad y ductilidad, y en el caso de blancos de hormigón, todas las fórmulas de penetración coinciden en la importancia de la resistencia a compresión, así como de la tenacidad y ductilidad de éste.

El objeto de este trabajo de investigación ha sido determinar el espesor que deben poseer blancos de diferentes hormigones reforzados con distintas cuantías de fibras de acero para evitar que proyectiles de varios calibres incidiendo normalmente sobre ellos puedan perforarlos o incluso producir "scabbing", a fin de que con la información obtenida puedan proyectarse protecciones balísticas para defensa de personal o de equipos.

\section{PLAN EXPERIMENTAL}

El plan experimental ha constado de dos partes: primera: diseño y caracterización de hormigones y fabricación de placas-blanco, y segunda: ensayos balísticos.

\subsection{Diseño y caracterización de hormigones y fabricación de placas-blanco}

Esta primera fase se realizó en el Laboratorio de Materiales de Construcción del Departamento de Ingeniería Civil-Construcción de la Universidad Politécnica de Madrid (LM-DICC-UPM). Los hormigones empleados en esta fase experimental fueron de dos tipos: uno convencional (HC) de resistencia característica a compresión de $30 \mathrm{MPa}$ y otro de alta resistencia (HAR) con resistencia característica a compresión de $80 \mathrm{MPa}$. Después de realizar varias dosificaciones y masas de prueba se adoptaron las dosificaciones que figuran en la Tabla 1. En los dos hormigones se empleó cemento CEM I 42,5R/SR con un contenido de $\mathrm{C}_{3} \mathrm{~S}$ del $71,9 \%$ y una superficie especifica de $400 \pm 25 \mathrm{~m}^{2} / \mathrm{kg} \mathrm{y}$, por tanto, con gran capacidad de generar tobermoritas secundarias mediante su reacción con humo de sílice cuyo conteniendo de $\mathrm{SiO}_{2}$ era del $93,5 \%$, con una superficie específica de $21.730 \mathrm{~m}^{2} / \mathrm{kg}$. significantly high compression in the concrete that is fragmented and at a high temperature as a consequence of the pressure waves. In addition to this, a strong friction effect with the body of the projectile exists that causes a growing loss of kinetic energy, which in turn halts the projectile in the inner part of the target. If this does not occur the target is perforated and the projectile exits via the rear surface at a lower velocity. When the projectile is notionally shapeless (as in the cases of those examined in this work), factors such as the deformation and loss of the form of the projectile tip that make theoretical study complex, are eliminated. In the process of energy absorption by the target, the form and mechanical properties of the projectile, especially toughness and ductility, are of high significance. In the case of concrete targets all penetration formulae agree as regards the importance of the compression strength and toughness, as well as the ductility of concrete.

The objective of this study, therefore, is to determine the thickness that targets made of concrete reinforced with different quantities of steel fibres require to prevent projectiles of varying calibres (that strike perpendicularly) from perforating the surface or even producing "scabbing". This will then allow the results obtained to be used in designing ballistic protection for the defence of personnel and equipment.

\section{THE EXPERIMENTAL PLAN}

The experimental plan consisted of two phases: first, the design and classification of concretes, and manufacture of plate-targets; and second, the ballistic tests.

\subsection{Design and classification of concretes and manufacture of plate-targets}

This phase was carried out in the construction materials laboratory in the Civil Engineering and Construction Department at the Universidad Politécnica de Madrid. The concretes used were of two types: a conventional concrete $(\mathrm{HC})$ of characteristic compression strength of $30 \mathrm{MPa}$ and a high-strength concrete (HAR) of characteristic compression strength of $80 \mathrm{MPa}$. After preparing various mixes of concretes, some were selected (see Table 1). As both concretes used cement CEM I $42,5 S R / R$ with a $C_{3} S$ content of $71.9 \%$, and a specific surface of $400 \pm 25 \mathrm{~m}^{2} / \mathrm{kg}$, they were suitable for generating secondary tobermorite through a reaction with a silica fume with $93.5 \%$ content of $\mathrm{SiO}_{2}$, with a specific surface of $21730 \mathrm{~m}^{2} / \mathrm{kg}$. 
Tabla 1 / Table 1

Dosificación de los HAR y HC empleados en los ensayos.

Mix proportions of HAR and HC used in the tests.

\begin{tabular}{|c|c|c|c|c|c|c|c|c|}
\hline Mezcla / Mix & $\begin{array}{l}\text { Cemento I } \\
\text { Cement (kg) }\end{array}$ & $\begin{array}{l}\text { Humo sílice I } \\
\text { Silica fume } \\
\text { (kg) }\end{array}$ & $\begin{array}{c}\text { Arena / Sand } \\
(0-5)(\mathrm{kg})\end{array}$ & $\begin{array}{c}\text { Árido } \\
\text { machacado / } \\
\text { Coarse } \\
\text { agrégate } \\
(6-12)(\mathbf{k g})\end{array}$ & $\begin{array}{c}\text { Agua I } \\
\text { Water (I) }\end{array}$ & $\begin{array}{l}\text { Plastificante/ } \\
\text { Plasticer (\%) }\end{array}$ & $\begin{array}{c}\text { Relación / } \\
\text { Ratio a/c }\end{array}$ & $\begin{array}{c}\text { Relación / } \\
\text { Ratio } \\
a / c+K f K=2\end{array}$ \\
\hline 1 & 500 (I) & 50 & 630 & 990 & 150 & $7.5(\mathrm{I})(1.5)$ & 0.30 & 0.26 \\
\hline 2 & 250 (I) & - & 630 & 990 & 162.5 & - & 0.65 & - \\
\hline
\end{tabular}

Los hormigones se amasaron en una amasadora planetaria de 100 I de capacidad. Al terminar el amasado se midió la consistencia del hormigón fresco mediante el cono de Abrams. La media de dos determinaciones, que en ambos casos era muy parecida, fue de $16 \mathrm{~cm}$ para el HAR y de $15 \mathrm{~cm}$ para el HC.

Con las masas elegidas se fabricaron probetas cilíndricas de $10 \times 20 \mathrm{~cm}$ y cúbicas de $10 \times 10 \times 10 \mathrm{~cm}$. El número de probetas de cada tipo, para cada edad, fue de tres, que fueron compactadas mediante mesa vibrante de $6.000 \mathrm{cpm}$. Las probetas se desmoldaron a las 24 horas y se almacenaron en una cámara de curado en condiciones normalizadas de $20 \pm 2^{\circ} \mathrm{C}$ y humedad relativa superior al $95 \%$.

Los ensayos de resistencia a compresión se realizaron a las edades de: 1 , 2, 3, 5, 7, 14, 28, 90, 120 y 180 días.

Los resultados obtenidos media de tres ensayos para cada edad y los factores de correlación entre probetas cilíndricas y cúbicas para cada edad son los que se indican en la Tabla 2.

El factor de paso de resistencia cúbica a cilíndrica era importante conocerlo a fin de evitar la dispersión que se obtiene en los ensayos a compresión de hormigones de alta resistencia como consecuencia del refrentado, por lo que se prefirió trabajar con probetas cúbicas al ser más cómodo y fiable. El control de las amasadas se realizó al $100 \%$.
The concretes were prepared in a mixer with a capacity of 1,00 I. On completion, the consistency of the concrete was established by means of the Abrams cone. The average slump identified for two of them was similar: 16 $\mathrm{cm}$ for the $H A R$ and $15 \mathrm{~cm}$ for the $H C$.

Cylindrical and cubic specimens were fabricated from the chosen mixes, with dimensions of $10 \times 20 \mathrm{~cm}$ and $10 \times$ $10 \times 10 \mathrm{~cm}$ respectively. The number of specimens for each type of concrete and for each age was three and they were compacted by means of a vibration test table at $6000 \mathrm{cpm}$. The specimens were demoulded after 24 hours and stored in a chamber at normalised conditions of $20 \pm 2{ }^{\circ} \mathrm{C}$ and relative humidity of $\geq 95 \%$.

The compression tests of the concretes were performed at one, two, three, five, seven, 14, 28, 90, 120 and 180 days.

The results of each three tests for each age and the correlation factor between cubic and cylindrical specimens are shown in Table 2.

It is important that the correlation factor between cylindrical and cubic strength be known, given the need to avoid the irregularity of results obtained in the compression tests of high-strength concretes as a consequence of capping, by which cubic specimens were considered the most suitable as they were also more viable. Control of the mixes was performed at $100 \%$.

Tabla 2 / Table 2

Comparación de los resultados de las resistencias a compresión de probetas cilíndricas y cúbicas de HAR y HC. Compression strength results of cylindrical and cubic speciments of HAR and HC.

\begin{tabular}{|c|c|c|c|c|c|c|c|c|c|c|}
\hline \multirow[b]{2}{*}{$\begin{array}{c}\text { Mezcla I } \\
\text { Mix }\end{array}$} & \multirow[b]{2}{*}{$\begin{array}{l}\text { Probeta I } \\
\text { Specimen }\end{array}$} & \multicolumn{9}{|c|}{ Resistencia media (MPa) y Valor del factor de correlación / Average strength (MPa) and correlation factor value } \\
\hline & & $\begin{array}{c}1 \text { día } / \\
\text { day }\end{array}$ & $\begin{array}{l}2 \text { días } I \\
\text { days }\end{array}$ & $\begin{array}{l}3 \text { días } I \\
\text { days }\end{array}$ & $\begin{array}{c}7 \text { días } I \\
\text { days }\end{array}$ & $\begin{array}{c}14 \text { días I } \\
\text { days }\end{array}$ & $\begin{array}{c}28 \text { días } I \\
\text { days }\end{array}$ & $\begin{array}{c}90 \text { días } I \\
\text { days }\end{array}$ & $\begin{array}{c}120 \text { días I } \\
\text { days }\end{array}$ & $\begin{array}{c}180 \text { días } / \\
\text { days }\end{array}$ \\
\hline \multirow{3}{*}{$1 \mathrm{HAR}$} & Cil. & 42.0 & 58.9 & 66.7 & 75.1 & 83.3 & 90.3 & 95.6 & 97.8 & 99.4 \\
\hline & Cúb. & 54.8 & 71.2 & 79.8 & 88.3 & 95.1 & 99.2 & 103.9 & 106.7 & 107.0 \\
\hline & Factor & 0.77 & 0.81 & 0.83 & 0.85 & 0.86 & 0.91 & 0.92 & 0.92 & 0.93 \\
\hline \multirow{3}{*}{$2 \mathrm{HC}$} & Cil. & 10.2 & 15.4 & 19.0 & 21.7 & 27.5 & 30.0 & 34.2 & 35.5 & 36.2 \\
\hline & Cúb. & 12.7 & 19.0 & 23.4 & 26.4 & 31.2 & 34.5 & 38.9 & 39.9 & 40.7 \\
\hline & Factor & 0.80 & 0.81 & 0.81 & 0.82 & 0.84 & 0.87 & 0.88 & 0.89 & 0.89 \\
\hline
\end{tabular}


Las fibras empleadas en el refuerzo de los hormigones fueron Dramix 60/80 de acero de alto contenido de carbono, obtenidas por trefilado, con extremos conformados y encoladas en forma de peines. Con ambos hormigones (HAR y HC) se emplearon contenidos de fibras de: $0,20,40,60$ y $80 \mathrm{~kg} / \mathrm{m}^{3}$.

Con los hormigones anteriormente indicados se fabricaron placas de $60 \times 60 \mathrm{~cm}$ con espesores de: 5, 10, 15, $20,25,35$ y $40 \mathrm{~cm}$ para el HAR y de $40 \mathrm{~cm}$ de espesor para el $\mathrm{HC}$. El número de placas de HAR ensayadas fue de 43, distribuidas en: 5 de $5 \mathrm{~cm}, 7$ de $10 \mathrm{~cm}, 6$ de 15 $\mathrm{cm}, 5$ de $20 \mathrm{~cm}, 3$ de $25 \mathrm{~cm}, 5$ de $35 \mathrm{~cm}$ y 6 de $40 \mathrm{~cm}$ de espesor; mientras que el número de placas ensayadas de $\mathrm{HC}$ fue solo 6 de $40 \mathrm{~cm}$ de espesor (Figura 1).

Dentro de las placas de diferentes espesores siempre, al menos una de ellas no contenía refuerzo de fibras. En las de $5 \mathrm{~cm}$ de espesor se empleaban cuantías de 20 o $40 \mathrm{~kg} / \mathrm{m}^{3}$ de fibras, dado que se iban a utilizar proyectiles de calibres pequeños de 7,62 y $12,70 \mathrm{~mm}$. En las de espesores de 10, 15 y $20 \mathrm{~cm}$ se emplearon cuantías de $20,40,60$ y $80 \mathrm{~kg} / \mathrm{m}^{3}$ con calibres de 7,62 y $12,70 \mathrm{~mm}$. En las placas de espesor $25 \mathrm{~mm}$ se emplearon cuantías de 20 y $40 \mathrm{~kg} / \mathrm{m}^{3}$ con calibre de $20 \mathrm{~mm}$ y en las placas de 35 y $40 \mathrm{~cm}$ se utilizaron sólo cuantías de 60 y $80 \mathrm{~kg} / \mathrm{m}^{3}$, dado que se iban a utilizar proyectiles de 20 y $25 \mathrm{~mm}$.

La designación de cada placa-blanco la formaba en primer lugar el tipo de hormigón empleado (HAR o HC), seguido del espesor, en cm (5, 10, 15, 20, 25, 35 o 40), continuando con el contenido de fibras, en $\mathrm{kg} / \mathrm{m}^{3}(0,20,40,60$ ó $80)$, y finalmente con un indicativo del número de la placa en el caso de existir más de una de las mismas características. Así, por ejemplo, HAR-15/60/2, indica que se trata de una placa de hormigón de alta resistencia, de
The fibres used in the reinforcement of concretes were Dramix 60/80 high-carbon content steel, obtained by drawing, with shaped ends and glued in the profile of combs. In the case of each concrete, the fibres content used was 0, 20, 40, 60 and $80 \mathrm{~kg} / \mathrm{m}^{3}$.

Plate-targets of $60 \times 60 \mathrm{~cm}$ were then made, with thicknesses of five, 10,15,20,25, 35 and $40 \mathrm{~cm}$ for the $H A R$ concrete, and of $40 \mathrm{~cm}$ for the $\mathrm{HC}$. The number of HAR plates tested was 43, distributed in the following groups: five of $5 \mathrm{~cm}$, seven of $10 \mathrm{~cm}$, six of $15 \mathrm{~cm}$, five of $20 \mathrm{~cm}$, three of $25 \mathrm{~cm}$, five of $35 \mathrm{~cm}$ and six of $40 \mathrm{~cm}$ thickness. The number of HC plates tested was only six of $40 \mathrm{~cm}$, as shown in Figure 1.

Among the plate-targets of different thicknesses, there remained always at least one of that contained no fibres. In those with a $5 \mathrm{~cm}$ thickness quantities of 20 or 40 $\mathrm{kg} / \mathrm{m}^{3}$ of fibres were used, given that small calibres (7.62 and $12.70 \mathrm{~mm}$ ) would be utilised. In those with a 10, 15 and $20 \mathrm{~cm}$ thickness, quantities of 20, 40, 60 and 80 $\mathrm{kg} / \mathrm{m}^{3}$ fibre were used with calibres of 7.62 and 12.70 $\mathrm{mm}$. In those with a $25 \mathrm{~cm}$ thickness, quantities of 20 and $40 \mathrm{~kg} / \mathrm{m}^{3}$ fibres were used with calibres of $20 \mathrm{~mm}$. Finally, in those with a 35 and $40 \mathrm{~cm}$ thickness, quantities of 60 and $80 \mathrm{~kg} / \mathrm{m}^{3}$ fibres were used, since they would utilise 20 and $25 \mathrm{~mm}$ calibre projectiles.

The designation of each plate-target involved the following: the type of concrete used (HAR or HC), the thickness in $\mathrm{cm}$ (five, 10,15, 20, 25, 35 or 40), the fibre content in $\mathrm{kg} / \mathrm{m}^{3}(0,20,40,60$ or 80$)$, and finally a code for the number of the plate in the case of there existing more than one with the same characteristics. For example, the plate-target HAC-15/60/2 indicated that it was a plate of high-strength concrete, $15 \mathrm{~cm}$ thickness,

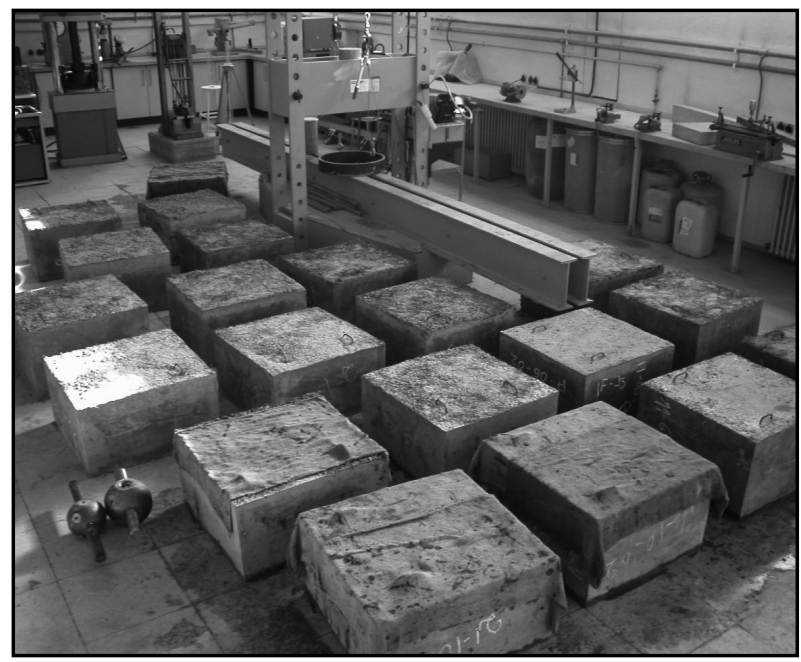

Figura 1. Almacenamiento de placas-blanco en el laboratorio. Figure 1. Storage of plates-target in the laboratory. 
$15 \mathrm{~cm}$ de espesor, con hormigón con $60 \mathrm{~kg} / \mathrm{m}^{3}$ de fibras de acero, y que es la segunda de las dos de iguales características que se ensaya.

Una vez fabricadas las placas se almacenaron en ambiente de laboratorio cubiertas con arpilleras hasta los 28 días de edad en que se transportaron al Polígono de Experiencias del Ejército (PEE) dependiente del Ministerio de Defensa, para efectuar los ensayos balísticos.

Todos los hormigones reforzados con fibras se ensayaron para determinar su tenacidad a flexión y a punzonamiento siguiendo, respectivamente, las normas UNE 83-510 y UNE 83-515. En el ensayo de tenacidad a flexión del HAR con diferente cuantía de fibras se obtuvieron: con $20 \mathrm{~kg} / \mathrm{m}^{3}$ de fibras una carga de primera fisura de $28,24 \mathrm{kN}$ y un índice de tenacidad $I_{30}$ de 16,65 . Con $40 \mathrm{~kg} / \mathrm{m}^{3}$ de fibras, la carga fue de $29,76 \mathrm{kN}$ e $\mathrm{I}_{30}$ de 28,51 . Para $60 \mathrm{~kg} / \mathrm{m}^{3}$ de fibras, los valores fueron: $31,38 \mathrm{kN} \mathrm{e} \mathrm{I}_{30}$ de 35,89 , y por último, para $80 \mathrm{~kg} / \mathrm{m}^{3}$ de fibras se obtuvo $30,48 \mathrm{kN}$ e $\mathrm{I}_{30}$ de 41,51 .

En el ensayo de punzonamiento se midió la carga de rotura, la flecha máxima y la tenacidad correspondiente de una flecha de $25 \mathrm{~mm}$ para los hormigones con fibras. Los hormigones ensayados han sido el $\mathrm{HC}$ sin fibras y el HAR sin fibras y con $80 \mathrm{~kg} / \mathrm{m}^{3}$ de fibras de acero. Los resultados obtenidos fueron: para el $\mathrm{HC}$ una carga de rotura de $40,78 \mathrm{kN}$, con flecha máxima de $0,88 \mathrm{~mm}$ y tenacidad 57,44 J. Para el HAR sin fibras, una carga de rotura de $72,78 \mathrm{kN}$ y flecha máxima de $1,50 \mathrm{~mm}$ y tenacidad $171,89 \mathrm{~J}$, y para el HAR con $80 \mathrm{~kg} / \mathrm{m}^{3}$ de fibras, una carga de rotura de $173,57 \mathrm{kN}$, y tenacidad de $3.536,6 \mathrm{~J}$ para flecha de $25 \mathrm{~mm}$.

\subsection{Ensayos balísticos}

Los ensayos balísticos se llevaron a cabo en el PEE si bien la interpretación y análisis de resultados se realizó en el LM-DICC-UPM. Los ensayos se realizaron dentro de una galería de tiro cubierta de $100 \mathrm{~m}$ de longitud, colocando las placas sujetas a un soporte de acero de rigidez suficiente para absorber los posibles desplazamientos que pudiesen provocar los impactos, fijándose estas al mismo mediante abrazaderas metálicas. Los soportes estaban posicionados en la galería de tiro de forma que el ángulo de incidencia del proyectil fuese prácticamente de 90 grados (Figura 2).

Los proyectiles utilizados en la primera fase de los ensayos con placas de hasta $20 \mathrm{~cm}$ fueron: 7,62 $\mathrm{mm}$ AP (NATO) y $12,70 \mathrm{~mm}$ M8. En la segunda fase se emplearon las placas de mayor espesor para proyectiles perforantes de $20 \mathrm{~mm}$ (Figura 3) y $25 \mathrm{~mm}$ APDS-T. with $60 \mathrm{~kg} / \mathrm{m}^{3}$ of steel fibres and that it corresponded to the second one of the two with equal characteristics.

Once the manufacture of the plate-targets was finished, they were stored in a laboratory environment and covered with hessian for 28 days at which time they were transported to the Polígono de Experiencias del Ejército (PEE), a Ministry of Defence range, to be subjected to ballistic testing.

All the concretes reinforced with fibres were tested to determine toughness and shear failure, in accordance with standards UNE 83-510 and UNE 83-515. In the toughness test of the HAR with different quantities of fibres the following were obtained: with $20 \mathrm{~kg} / \mathrm{m}^{3}$ of fibres, a load to first fissure of $28.24 \mathrm{kN}$ and a toughness index $I_{30}$ of 16.65 ; with $40 \mathrm{~kg} / \mathrm{m}^{3}$ of fibres the values were $29.76 \mathrm{kN}$ and $I_{30}$ of 28.51; for $60 \mathrm{~kg} / \mathrm{m}^{3}$ fibres the values were $31.38 \mathrm{kN}$ and $\mathrm{I}_{30}$ of 35.89 ; and finally for 80 $\mathrm{kg} / \mathrm{m}^{3}$ fibres $30.48 \mathrm{kN}$ and $I_{30}$ of 41.51 .

In the shear test, the break load, maximum deflection and the toughness corresponding to a deflection of 25 $\mathrm{mm}$ were measured. The concretes tested were the $\mathrm{HC}$ without fibres, and the HAR without fibres and with 80 $\mathrm{kg} / \mathrm{m}^{3}$ of steel fibres. The results obtained were the following: for the $\mathrm{HC}$ a break load of $40.78 \mathrm{kN}$ with 0.88 $\mathrm{mm}$ maximum deflection and $57.44 \mathrm{~J}$ toughness; for $\mathrm{HC}$ without fibres a break load of $72.78 \mathrm{kN}$ with $1.50 \mathrm{~mm}$ maximum deflection and $171.89 \mathrm{~J}$ toughness; and for HAC with $80 \mathrm{~kg} / \mathrm{m}^{3}$ of fibres, a break load of $173.57 \mathrm{kN}$, $25 \mathrm{~mm}$ deflection, and $3536.6 \mathrm{~J}$ toughness.

\subsection{The ballistic tests}

The ballistics tests were carried out at the previously mentioned Ministry of Defence range, and examination and analysis of the results was done so at the UPM. The tests were performed in an indoor shooting range with a length of $100 \mathrm{~m}$, and the plates fixed by metal clips to a support of sufficient mechanical rigidity to absorb the possible displacements that could occur at impact. The supports were then placed in the shooting range in a position so that the incident angle of the projectile was at practically 900, as shown in Figure 2.

The projectiles used in the first phase of the tests with plates of up to $20 \mathrm{~cm}$ thickness were 7.62 AP (NATO) and $12.70 \mathrm{~mm} \mathrm{MB}$. In the second phase, plates of greater thickness were used for projectiles of $20 \mathrm{~mm}$, as shown in Figure 3, and $25 \mathrm{~mm}$ for APDAS-T. 


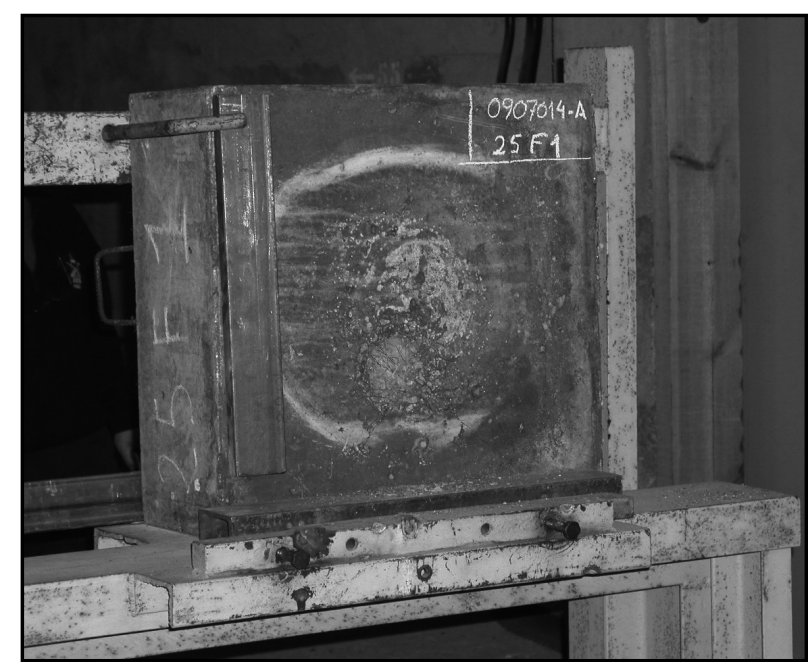

Figura 2. Placa-blanco de $25 \mathrm{~cm}$ de espesor fijada al soporte. Figure 2. $25 \mathrm{~cm}$ thickness plate-target fixed to the bracket.

En la primera fase de los ensayos balísticos se varío la velocidad de salida del proyectil de 7,62 AP, modificando la carga de pólvora del cartucho, mientras que la variación de ésta se hacía en los proyectiles de 12,70 M8, empleando dos cañones probeta de diferente longitud de tubo. Esta forma de actuar tenía por finalidad determinar el "factor de frenado" del que se habla posteriormente.

Con los proyectiles de $7,62 \mathrm{~mm}$ y $12,70 \mathrm{~mm}$, la distancia entre el arma y la cara frontal del blanco era de $15 \mathrm{~m}$, mientras que para los proyectiles de $20 \mathrm{~mm}$ la distancia armablanco pasó a ser de $30 \mathrm{~m}$, elevándose ésta a $46 \mathrm{~m}$ para los proyectiles de $25 \mathrm{~mm}$. Con estas distancias se conseguía una adecuada estabilidad de vuelo de los proyectiles.

La toma de datos de los ensayos se efectuó mediante radares Doppler y cámaras ultrarrápidas (Figura 4). El emisor del radar se situó debajo de la boca del arma y se activó en el instante del disparo a fin de medir la velocidad

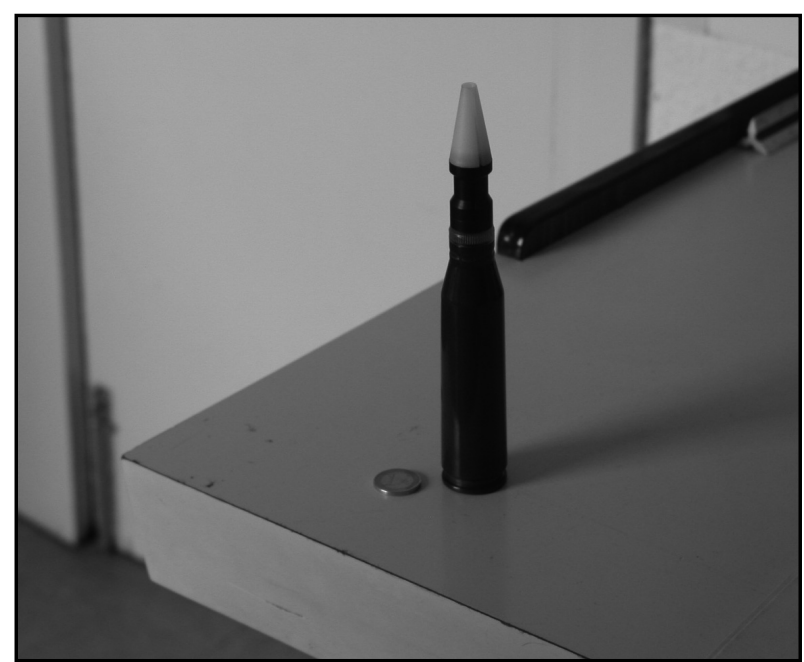

Figura 3. Proyectil de $20 \mathrm{~mm}$ APDS

Figure 3. $20 \mathrm{~mm}$ APDS projectile.

In the first phase of the ballistic tests the velocity of the projectiles was varied from 7.62AP, modifying the gunpowder load of the cartridge, while the variation of velocity of the $12.70 \mathrm{~mm}$ projectiles was made by using two specimens with different tube lengths. The objective was to determine the "braking factor", which will be examined later.

In the cases of the $7.62 \mathrm{~mm}$ and $12.70 \mathrm{~mm}$ projectiles, the distance between the gun and the frontal face of the plate-target was $15 \mathrm{~m}$, whereas for $20 \mathrm{~mm}$ projectiles it was $30 \mathrm{~m}$, increasing to $46 \mathrm{~m}$ for $25 \mathrm{~mm}$ projectiles. An adequate degree of projectile flight stabilisation was duly obtained.

The capture of data from the tests was performed by means of Doppler radars and ultra-fast cameras, as shown in Figure 4. The radar transmitter was placed under the end of the barrel of the firearm and activated,

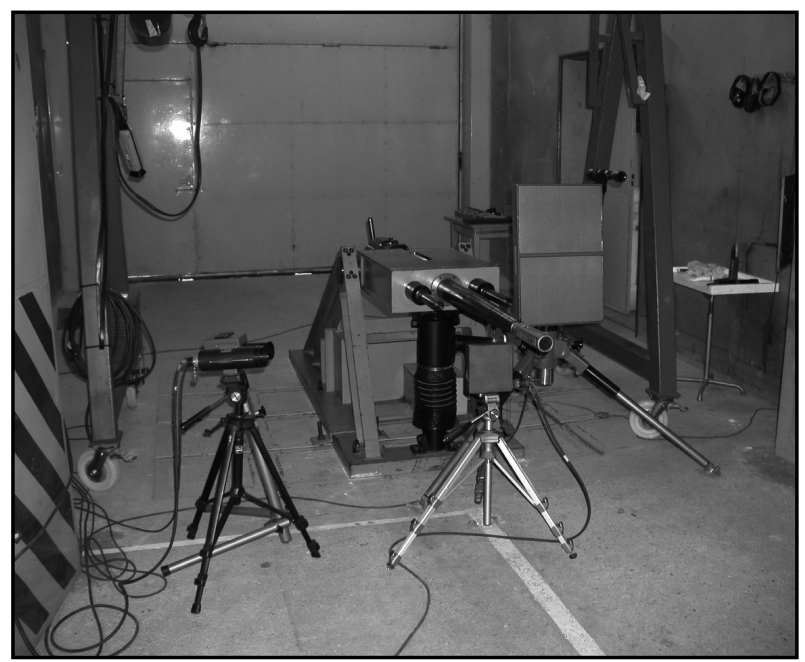

Figura 4. Cañón de 25 mm, rádares Doppler y cámaras ultrarrápidas. Figure 4. $25 \mathrm{~mm}$ cannon, Doppler radars and extra fast camera. 
en boca del arma. En las proximidades de la cara anterior y posterior de la placa se colocaron otros radares para medir la velocidad de impacto y la velocidad de salida del proyectil en el caso de perforación del blanco, en cuyo caso una cámara ultrarrápida fotografiaba el vuelo del proyectil a su salida. in order to measure the velocity of the projectile in the mouth of the firearm, at the instant of the shot. In the proximity of the front and rear surfaces of the plate, other radars were placed to measure the velocities of entrance and exit of the projectile should there have been a perforation of the plate, in which case the ultrafast cameras would have filmed the flight of the projectile after exit.

Tabla 3 / Table 3

Comportamiento de las placas ensayadas frente a impacto de los diferentes proyectiles. Behavior of the tested plates to impact of the different proyectiles.

\begin{tabular}{|c|c|c|c|c|c|c|}
\hline $\begin{array}{c}\text { Designación / } \\
\text { Designation }\end{array}$ & $\begin{array}{c}\text { Calibre proyectil / } \\
\text { Caliber projectile } \\
\text { (mm) }\end{array}$ & $\begin{array}{l}\text { Volumen medio / } \\
\text { Average } \\
\text { "spalling" } \\
\text { volume }(\mathrm{cm})\end{array}$ & \begin{tabular}{|} 
Volumen medio / \\
Average \\
"scabbing" \\
volume $(\mathrm{cm})$
\end{tabular} & $\begin{array}{c}\text { Comportamiento / } \\
\text { Behaviour }\end{array}$ & $\begin{array}{c}\text { Profundidad de } \\
\text { penetración / } \\
\text { Deep penetration x } \\
(\mathrm{mm})\end{array}$ & $\begin{array}{l}\text { Profundidad- } \\
\text { espesor / Deep } \\
\text { thickness } x / \mathrm{e}\end{array}$ \\
\hline HAR-5/0 & 7.62 & 42 & 87 & Perforada / Perforated & - & - \\
\hline HAR-5/20/1 & 7.62 & 34 & 75 & Perforada / Perforated & - & - \\
\hline HAR-5/40/1 & 7.62 & 29 & 70 & No perforada / Non perforated & 22 & 0.44 \\
\hline HAR-5/40/2 & 12.70 & 60 & 155 & No perforada / Non perforated & - & - \\
\hline HAR-10/0/1 & 7.62 & 110 & 0 & No perforada / Non perforated & 40 & 0.40 \\
\hline HAR-10/0/2 & 7.62 & 76 & 0 & No perforada / Non perforated & 42 & 0.42 \\
\hline HAR-10/20/1 & 12.70 & 103 & 202 & Perforada / Perforated & - & - \\
\hline HAR-10/40/1 & 12.70 & 140 & 167 & Perforada / Perforated & - & - \\
\hline HAR-10/60/1 & 12.70 & 102 & 165 & Perforada / Perforated & - & - \\
\hline HAR-10/80/1 & 12.70 & 136 & 0 & No perforada / Non perforated & 52 & 0.52 \\
\hline HAR-15/0/1 & 7.62 & 63 & 0 & No perforada / Non perforated & 33 & 0.22 \\
\hline HAR-15/20/1 & 12.70 & 158 & 0 & No perforada / Non perforated & - & - \\
\hline HAR-15/40/1 & 12.70 & 152 & 0 & No perforada / Non perforated & - & - \\
\hline HAR-15/60/1 & 12.70 & 140 & 0 & No perforada / Non perforated & 67 & 0.47 \\
\hline HAR-15/60/2 & 12.70 & 125 & 0 & No perforada / Non perforated & 74 & 0.49 \\
\hline HAR-20/0/1 & 12.70 & 320 & 0 & No perforada / Non perforated & 90 & 0.45 \\
\hline HAR-20/20/1 & 12.70 & 203 & 0 & No perforada / Non perforated & 55 & 0.28 \\
\hline HAR-20/20/2 & 12.70 & 232 & 0 & No perforada / Non perforated & 56 & 0.28 \\
\hline HAR-20/40/1 & 20.00 & 430 & 850 & Perforada / Perforated & - & - \\
\hline HAR-25/0/1 & 20.00 & - & - & Rotura placa / Break of plate & - & - \\
\hline HAR-25/20/1 & 20.00 & 490 & 600 & Perforada / Perforated & - & - \\
\hline HAR-25/40/1 & 20.00 & 425 & 550 & Perforada / Perforated & - & - \\
\hline HAR-35/0/1 & 20.00 & - & - & Rotura placa / Break of plate & - & - \\
\hline HAR-35/20/1 & 20.00 & 430 & 630 & Perforada / Perforated & - & - \\
\hline HAR-35/40/1 & 20.00 & 280 & 600 & No perforada / Non perforated & 260 & 0.74 \\
\hline HAR-35/60/1 & 25.00 & 800 & 0 & No perforada / Non perforated & 220 & 0.63 \\
\hline HAR-35/80/1 & 25.00 & 465 & 0 & No perforada / Non perforated & 200 & 0.57 \\
\hline HAR-40/0/1 & 20.00 & - & - & Rotura placa / Break of plate & - & - \\
\hline HAR-40/0/2 & 25.00 & - & - & Rotura placa / Break of plate & - & - \\
\hline HAR-40/20/1 & 20.00 & 435 & 0 & No perforada / Non perforated & 250 & 0.62 \\
\hline HAR-40/40/1 & 20.00 & 700 & 0 & No perforada / Non perforated & 220 & 0.55 \\
\hline HAR-40/60/1 & 25.00 & 524 & 0 & No perforada / Non perforated & 280 & 0.70 \\
\hline HAR-40/80/1 & 25.00 & 400 & 0 & No perforada / Non perforated & 210 & 0.52 \\
\hline $\mathrm{HC}-40 / 0 / 1$ & 20.00 & - & - & Rotura placa / Break of plate & - & - \\
\hline $\mathrm{HC}-40 / 0 / 2$ & 25.00 & - & - & Rotura placa / Break of plate & - & - \\
\hline $\mathrm{HC}-40 / 20 / 1$ & 20.00 & 250 & 450 & Perforada / Perforated & - & - \\
\hline $\mathrm{HC}-40 / 40 / 1$ & 20.00 & 395 & 440 & Perforada / Perforated & - & - \\
\hline $\mathrm{HC}-40 / 60 / 1$ & 25.00 & 340 & 465 & Perforada / Perforated & - & - \\
\hline HC- $40 / 80 / 1$ & 25.00 & 295 & 450 & Perforada / Perforated & - & - \\
\hline
\end{tabular}


Una vez realizado el disparo y registradas con los rádares la velocidad de impacto y salida del proyectil, en el caso en que éste perforase, se procedía a un examen visual de cada placa, tomas fotográficas de las mismas, medición de los volúmenes de los cráteres de entrada "spalling" y de salida "scabbing" del proyectil por medio de arena muy fina (impalpable), de densidad conocida, y medición de la profundidad de los cráteres por medio de un calibre especial. Conviene indicar que no fue posible medir la velocidad de salida de los proyectiles de $25 \mathrm{~mm}$ y de algunos de $20 \mathrm{~mm}$ debido al efecto sombra que producían los fragmentos de hormigón desprendidos en el trasdós. Como datos totalmente fiables, se midieron las velocidades de salida de los de calibre $12,70 \mathrm{~mm}$ correspondientes a los hormigones designados en la Tabla 3 como HAR-10/40/1 y HAR-10/60/1 que fueron respectivamente $228 \mathrm{~m} / \mathrm{s}$ y $205 \mathrm{~m} / \mathrm{s}$, así como la del proyectil del calibre $20 \mathrm{~mm}$ designado como HAR-25/40/1, cuya velocidad de salida fue de $105 \mathrm{~m} / \mathrm{s}$. Estos datos los emplearemos posteriormente en el apartado siguiente de análisis de resultados.

En la Tabla 3 se recogen también los resultados obtenidos de volúmenes de "spalling" y "scabbing" después de los ensayos, así como del comportamiento de las placas, indicando si ha existido perforación o solamente penetración y, en este caso, la profundidad alcanzada por el proyectil con respecto a la cara frontal y la relación entre ella y el espesor de la placa. En los proyectiles que no llegaban a perforar se midió la profundidad de penetración con un alambre trenzado flexible.

En la Tabla 4 se recogen los datos de las placas ensayadas, calibre y masa de los proyectiles empleados, la velocidad de impacto y la energía cinética en el momento del impacto. En la Tabla 5 aparece resumido el comportamiento de las distintas placas de acuerdo con la resistencia a compresión del hormigón, cuantía de fibras empleada, espesor de la placa y calibre de proyectil que incide sobre ellas.

\section{ANÁLISIS DE LOS RESULTADOS}

Poder emplear probetas cúbicas en todos los ensayos de control del HAR, antes de hacer la adición de fibras al hormigón, a fin de comprobar sus características resistentes y su uniformidad, evitó los problemas inherentes al refrentado de las probetas cilíndricas. Como se aprecia en la Tabla 2 el factor de paso de resistencia cúbica a cilíndrica es de 0,91 , siendo éste el valor empleado durante el control.

El aumento de la tenacidad de los hormigones reforzados con fibras quedó puesto de manifiesto en los ensayos de punzonamiento y de flexión realizados; en ellos se observó que la tenacidad frente a punzonamiento se
Once the shot had been made and the velocities of entrance and exit of the projectiles recorded by the radar, in the case of there having been perforation, a visual inspection of every plate, of the film, and measurement of the volumes of the entrance craters (or "spalling"), and exit craters (or "scabbing"), was carried out. This involved use of a fine sand of a known density to measure the volume of the craters, and a special calibre to measure the depth of them. It should be noted that measurement of the velocity at exit of the $25 \mathrm{~mm}$ projectiles and a certain amount of the $20 \mathrm{~mm}$ ones was not possible, due to the effect of the shadow produced by the fragments of concrete detached in the rear surface of the plates. As completely viable data, the velocity at exit of the 12.70 $\mathrm{mm}$ calibre projectiles shown in Table 3 as HAR-10/40/1 and HAR-10/60/1, were respectively of $228 \mathrm{~m} / \mathrm{s}$ and 205 $\mathrm{m} / \mathrm{s}$, as well as the $20 \mathrm{~mm}$ projectile shown as HAR25/40/1 that had a velocity at exit of $105 \mathrm{~m} / \mathrm{s}$. This data will be examined in the next section.

In Table 3 the results obtained for volumes of "spalling" and "scabbing" after the tests, as well as the behaviour of the plates, are shown. Also presented is an indication of whether perforation or only penetration has taken place and, should this have been the case, the depth reached by the projectile as regards the frontal surface and the relation between this and the thickness of the plate. In the cases of the projectiles that did not perforate the plate-target, the depth of penetration was measured by means of a flexible wire.

In Table 4 data of the tested plates, calibre and mass of the projectiles, the impact velocity and the kinetic energy at the moment of impact are shown. In addition, in Table 5 the behaviour of the different plates according to the compression strength of the concrete, quantity of fibres used, thickness of the plates and calibre of the respective projectile are summarised.

\section{ANALYSIS OF THE RESULTS}

Use of cubic specimens to verify the mechanical and uniformity of concretes, before adding fibres to them, avoided those problems that are common in the capping of cylindrical specimens. As shown in Table 2 the factor of passing from cubic to cylindrical strength was 0.91, with this value being duly used.

The increase of the toughness of fibre-reinforced concrete was shown in the shear failure tests performed. In both it was observed that toughness against shear failure was multiplied by three as the compression 
Tabla 4 / Table 4

Características balísticas de los proyectiles y energía de impacto sobre cada placa.

Balistic characteristics of de projectiles and impact energy on every plate.

\begin{tabular}{|c|c|c|c|c|c|c|c|}
\hline $\begin{array}{c}\text { Designación / } \\
\text { Designation }\end{array}$ & $\begin{array}{l}\text { Espesor placa / } \\
\text { Plate thickness } \\
\text { (cm) }\end{array}$ & $\begin{array}{c}\text { Contenido fibras } \\
\text { / Fibrecontent } \\
\left(\mathrm{kg} / \mathrm{m}^{3}\right)\end{array}$ & $\begin{array}{c}\text { Proyectil calibre } \\
\text { / Caliber project } \\
\text { (mm) }\end{array}$ & $\begin{array}{c}\text { Número } \\
\text { disparos por } \\
\text { placa / Shots } \\
\text { number for plate }\end{array}$ & $\begin{array}{c}\text { Velocidad media } \\
\text { impacto I } \\
\text { Average velocity } \\
\text { of impact }(\mathrm{m} / \mathrm{s})\end{array}$ & $\begin{array}{c}\text { Masa del } \\
\text { proyectil / } \\
\text { Projectile mass } \\
\text { (g) }\end{array}$ & $\begin{array}{l}\text { Energía cinética } \\
\text { impacto / } \\
\text { Kinetics impact } \\
\text { energy (kJ) }\end{array}$ \\
\hline HAR-5/0 & \multirow{4}{*}{5} & 0 & 7.62 & 3 & 780 & 9.45 & 2.88 \\
\hline HAR-5/20/1 & & 20 & 7.62 & 5 & 719 & $"$ & 2.44 \\
\hline HAR-5/40/1 & & 40 & 7.62 & 3 & 832 & $"$ & 3.27 \\
\hline HAR-5/40/2 & & $"$ & 12.70 & 2 & 859 & 25.00 & 9.22 \\
\hline HAR-10/0/1 & \multirow{6}{*}{10} & 0 & 7.62 & 8 & 882 & 9.45 & 3.68 \\
\hline HAR-10/0/2 & & $"$ & 7.62 & 3 & 840 & $"$ & 3.33 \\
\hline HAR-10/20/1 & & 20 & 12.70 & 4 & 874 & 25.00 & 9.55 \\
\hline HAR-10/40/1 & & 40 & 12.70 & 3 & 912 & $"$ & 10.40 \\
\hline HAR-10/60/1 & & 60 & 12.70 & 3 & 932 & $"$ & 10.86 \\
\hline HAR-10/80/1 & & 80 & 12.70 & 3 & 816 & $"$ & 8.32 \\
\hline HAR-15/0/1 & \multirow{5}{*}{15} & 0 & 7.62 & 3 & 816 & 9.45 & 3.15 \\
\hline HAR-15/20/1 & & 20 & 12.70 & 3 & 873 & 25.00 & 9.46 \\
\hline HAR-15/40/1 & & 40 & 12.70 & 3 & 857 & $"$ & 9.18 \\
\hline HAR-15/60/1 & & 60 & 12.70 & 3 & 858 & $"$ & 9.20 \\
\hline HAR-15/60/2 & & $"$ & 12.70 & 2 & 942 & $"$ & 11.09 \\
\hline HAR-20/0/1 & \multirow{4}{*}{20} & 0 & 12.70 & 1 & 852 & 25.00 & 9.07 \\
\hline HAR-20/20/1 & & 20 & 12.70 & 3 & 858 & $"$ & 9.20 \\
\hline HAR-20/20/2 & & $"$ & 12.70 & 2 & 855 & $"$ & 9.14 \\
\hline HAR-20/40/1 & & 40 & 20.00 & 1 & 1252 & 72.00 & 56.43 \\
\hline HAR-25/0/1 & \multirow{3}{*}{25} & 0 & 20.00 & 1 & 1254 & 72.00 & 55.61 \\
\hline HAR-25/20/1 & & 20 & 20.00 & 1 & 1259 & $"$ & 57.06 \\
\hline HAR-25/40/1 & & 40 & 20.00 & 1 & 1254 & $"$ & 56.61 \\
\hline HAR-35/0/1 & \multirow{5}{*}{35} & 0 & 20.00 & 1 & 1254 & 72.00 & 55.61 \\
\hline HAR-35/20/1 & & 20 & 20.00 & 1 & 1276 & $"$ & 58.61 \\
\hline HAR-35/40/1 & & 40 & 20.00 & 1 & 1266 & $"$ & 57.70 \\
\hline HAR-35/60/1 & & 60 & 25.00 & 1 & 1315 & 121.00 & 104.62 \\
\hline HAR-35/80/1 & & 80 & 25.00 & 1 & 1324 & $"$ & 106.06 \\
\hline HAR-40/0/1 & \multirow{6}{*}{40} & 0 & 20.00 & 1 & 1260 & 72.00 & 57.15 \\
\hline HAR-40/0/2 & & $"$ & 25.00 & 1 & 1320 & 121.00 & 105.41 \\
\hline HAR-40/20/1 & & 20 & 20.00 & 1 & 1268 & 72.00 & 57.88 \\
\hline HAR-40/40/1 & & 40 & 20.00 & 1 & 1261 & $"$ & 57.24 \\
\hline HAR-40/60/1 & & 60 & 25.00 & 1 & 1296 & 121.00 & 101.62 \\
\hline HAR-40/80/1 & & 80 & 25.00 & 1 & 1315 & $"$ & 104.62 \\
\hline $\mathrm{HC}-40 / 0 / 1$ & \multirow{6}{*}{40} & 0 & 20.00 & 1 & 1252 & 72.00 & 56.43 \\
\hline $\mathrm{HC}-40 / 0 / 2$ & & $"$ & 25.00 & 1 & 1291 & 121.00 & 100.83 \\
\hline $\mathrm{HC}-40 / 20 / 1$ & & 20 & 20.00 & 1 & 1257 & 72.00 & 56.88 \\
\hline $\mathrm{HC}-40 / 40 / 1$ & & 40 & 20.00 & 1 & 1266 & $"$ & 57.70 \\
\hline $\mathrm{HC}-40 / 60 / 1$ & & 60 & 25.00 & 1 & 1319 & 121.00 & 105.26 \\
\hline $\mathrm{HC}-40 / 80 / 1$ & & 80 & 25.00 & 1 & 1314 & $"$ & 104.46 \\
\hline
\end{tabular}

multiplica por 3 por el hecho de pasar la resistencia a compresión del hormigón de $30 \mathrm{MPa}$ a $80 \mathrm{MPa}$, multiplicándose por 21 cuando pasaba de no tener fibras a incorporar $80 \mathrm{~kg} / \mathrm{m}^{3}$. Con respecto a la tenacidad a flexión, medida por el índice $\mathrm{I}_{30}$, se observó que los incrementos eran notables, siendo crecientes desde el valor de 16,65 que corresponde a un hormigón HAR con $20 \mathrm{~kg} / \mathrm{m}^{3}$ de fibras, al de 41,51 que corresponde a uno de $80 \mathrm{~kg} / \mathrm{m}^{3}$ de fibras. strength of the concrete passed from $30 \mathrm{MPa}$ to $80 \mathrm{MPa}$, with it being multiplied by 21 when moving from having no fibres to having those of $80 \mathrm{~kg} / \mathrm{m}^{3}$. In the case of the flexion toughness measured by the index $I_{30}$, a notable increase was observed, with there being an increase from the value 16.65 in the case of HAR concrete with $20 \mathrm{~kg} / \mathrm{m}^{3}$ of fibres, to 41.51 to that with $80 \mathrm{~kg} / \mathrm{m}^{3}$. 
Tabla 5 / Table 5

Tabla resumen del comportamiento frente a impacto de las placas de HAR y HC con diferente contenido de fibras de acero. Summarize table of the behaviour to impact of HAR and HC plates with different steel fibre content.

\begin{tabular}{|c|c|c|c|c|c|c|c|c|c|}
\hline \multicolumn{10}{|c|}{ Tipo hormigón / Concrete type } \\
\hline \multicolumn{9}{|c|}{ HAR-100 } & HC-30 \\
\hline \multirow{2}{*}{$\begin{array}{c}\text { Contenido } \\
\text { fibras / Fibre } \\
\text { content } \\
\left(\mathrm{kg} / \mathrm{m}^{3}\right)\end{array}$} & \multirow{2}{*}{\begin{tabular}{|c|} 
Proyec. \\
Calibre I \\
Projectile \\
caliber $(\mathrm{mm})$
\end{tabular}} & \multicolumn{8}{|c|}{ Espesor de placa / Thickness of plate (cm) } \\
\hline & & 5 & 10 & 15 & 20 & 25 & 35 & 40 & 40 \\
\hline \multirow{4}{*}{0} & 7.62 & P-S & NP-NS & NP-NS & - & - & - & - & - \\
\hline & 12.70 & - & - & - & NP-NS & - & - & - & - \\
\hline & 20.00 & - & - & - & - & P-RB & P-RB & P-RB & P-RB \\
\hline & 25.00 & - & - & - & - & - & - & P-RB & P-RB \\
\hline \multirow{4}{*}{20} & 7.62 & $\mathrm{P}-\mathrm{S}$ & NP-NS & NP-NS & - & - & - & - & - \\
\hline & 12.70 & - & - & NP-NS & NP-NS & $\mathrm{P}-\mathrm{S}$ & - & - & - \\
\hline & 20.00 & - & - & - & - & - & P-S & NP-NS & P-S \\
\hline & 25.00 & - & - & - & - & - & - & - & - \\
\hline \multirow{4}{*}{40} & 7.62 & NP-S & - & - & - & - & - & - & - \\
\hline & 12.70 & P-S & - & NP-NS & - & - & - & - & - \\
\hline & 20.00 & - & P-S & - & P-S & P-S & NP-S & NP-NS & P-S \\
\hline & 25.00 & - & - & - & - & - & - & - & - \\
\hline \multirow{4}{*}{60} & 7.62 & - & - & - & - & - & - & - & - \\
\hline & 12.70 & - & P-S & NP-NS & - & - & - & - & - \\
\hline & 20.00 & - & - & - & - & - & - & - & - \\
\hline & 25.00 & - & - & - & - & - & NP-NS & NP-NS & P-S \\
\hline \multirow{4}{*}{80} & 7.62 & - & - & - & - & - & - & - & - \\
\hline & 12.70 & - & NP-NS & - & - & - & - & - & - \\
\hline & 20.00 & - & - & - & - & - & - & - & - \\
\hline & 25.00 & - & - & - & - & - & NP-NS & NP-NS & P-S \\
\hline
\end{tabular}

$\mathrm{P}=$ perfora / perforate; NP = no perfora / no perforate; S = "scabbing"; NS = no "scabbing"; RB = rotura placa / break of plate.

El "factor de frenado" $K$, que ejerce un blanco masivo sobre un proyectil que incide normalmente sobre la superficie del mismo y lo atraviesa, no perdiendo prácticamente masa durante la perforación, como ocurre con los proyectiles perforantes de tungsteno empleados en este trabajo, se puede considerar (8) de una forma aproximada como [1]:
The "braking factor" $K$ that corresponds to a massive target being hit by a projectile that strikes its surface and then crosses it, and not losing practically any mass during the perforation (as is the case of armour-piercing tungsten projectiles used in this work), can be considered (8) approximately as [1]:

$$
K=\left(E_{i}-E_{s}\right) / e=\Delta E / e
$$

Siendo $E_{i}$ la energía cinética de impacto; $E_{s}$ la energía cinética de salida del proyectil y e el espesor del banco.

El valor de $K$ caracteriza de una forma muy aproximada a cada hormigón de una resistencia a compresión y contenido de fibras determinado, como la resistencia al impacto del mismo frente a cada tipo de proyectil, independientemente de la velocidad del mismo y del espesor del blanco. Dicho valor se obtiene de forma experimental mediante los resultados de un número de disparos determinado sobre un mismo blanco, con lo cual se obtiene el valor medio y la desviación típica y, por tanto, los valores límites entre los que está comprendido el factor $K$.
With the following being: $E_{i}$ the kinetic energy at impact; $E_{s}$ the kinetic energy at projectile exit, and e the thickness of the target.

The value of $K$ classifies, in a highly approximate manner, each concrete with compression strength and fibre content, as the strength at strike of concrete against any type of projectile, regardless of the projectile velocity and target thickness. Such a value is obtained in an experimental form by means of the results of a number of shots against the same target, with which the average value and typical deviation are obtained, and therefore the limit values of the $K$ factor. 
Si se considera que la energía cinética residual, o de salida, $E_{s}$ como nula, se obtiene un valor crítico $K_{c r i t}$ con el cual se puede determinar la profundidad de perforación $t_{\text {perf }} \leq E_{i} / K_{\text {crit }}$

La "profundidad límite de scabbing" $s$, es la que tiene que alcanzar en su penetración un proyectil para que se produzca el "scabbing". Una vez que el proyectil ha alcanzado este límite y el hormigón se ha fracturado, aquel puede avanzar más fácilmente perforándolo. Normalmente, la distancia $s$ depende de la masa, forma, material y velocidad del proyectil, así como de las características mecánicas del blanco, en el caso del hormigón de su resistencia a compresión y ductilidad.

El riesgo de que se produzca "scabbing" se puede indicar, de forma general, como una función de la profundidad alcanzada por el proyectil en su penetración $x, y$ del espesor del blanco e. En el $\mathrm{HC}$ con $40 \mathrm{~kg} / \mathrm{m}^{3}$ de fibras de refuerzo el riesgo de "scabbing" es alto cuando la profundidad a la que llega el proyectil alcanza, o supera, el $45 \%$ del espesor del blanco, alcanzando el 60 o $65 \%$ con contenidos de fibras iguales o superiores a $60 \mathrm{~kg} / \mathrm{m}^{3}$ (6-8). En el HAR que hemos utilizado en este trabajo este valor puede estimarse, según los resultados de los ensayos de penetración, en el $75 \%$ para un contenido de fibras de $40 \mathrm{~kg} / \mathrm{m}^{3}$, alcanzando el $80 \%$ para contenidos superiores a $60 \mathrm{~kg} / \mathrm{m}^{3}$.

Para determinar el espesor que debe poseer una placablanco para absorber la energía con la que impacta un proyectil se hace un balance de la energía absorbida por la misma, de acuerdo con la expresión anteriormente indicada y apoyándose en la Tabla 3. En los dos ejemplos siguientes se indica el proceso a seguir: En el caso de hormigón designado por HAR-10/40/1, sometido a disparos de calibre $12,70 \mathrm{~mm}$, con una masa $m=25 \mathrm{~g}$, y velocidad de impacto $v i=912 \mathrm{~m} / \mathrm{s}$, que, según se ha indicado en el apartado anterior, tiene una velocidad de salida $v s=228 \mathrm{~m} / \mathrm{s}$, dado que la masa del proyectil prácticamente no varía durante la perforación, las energías cinéticas de entrada y salida serían respectivamente $E_{i}=10,40 \mathrm{~kJ}$ y $E_{S}=0,65 \mathrm{~kJ}$, por tanto, la energía absorbida por la placa será $\Delta E=9,75 \mathrm{~kJ}, \mathrm{y}$ el factor de frenado $K$, o energía absorbida por centímetro de espesor del blanco: $\Delta E / e=9,75 / 10=0,97 \mathrm{~kJ} / \mathrm{cm}$; el valor de $K$ determinado está dentro de los rangos deducidos por Moreno y Cánovas (7). Por consiguiente, el proyectil penetrará hasta una profundidad $x=10,40 \mathrm{~kJ} / 0,97 \mathrm{~kJ} / \mathrm{cm}=$ $10,72 \mathrm{~cm}$, y si el "scabbing" se produce cuando la relación entre la profundidad a la que llega el proyectil y el espesor del blanco es de $x / e \leq 0,75$, como se ha indicado con anterioridad, el espesor que deberá tener éste para que no se produzca "scabbing" será de 12,72/0,75 = 14,3 cm, luego si éste tiene $15 \mathrm{~cm}$ de espesor no se perforará ni presentará "scabbing", como así se comprueba en los
If it is considered that the residual kinetic energy, or exit energy, $E_{s}$ is null, a critical value $E_{c r i t}$ is obtained with which the depth of perforation, $t_{\text {perf }}=\leq E_{i} / K_{\text {crit }}$ can in turn be established.

The depth limit of "scabbing" $s$ is that which penetration by a projectile is required to reach for "scabbing" to occur. Once the projectile has reached this limit and the concrete has been fractured, it can advance more easily in its perforation of the target. Routinely, the distance $s$ depends on the mass, form, material and velocity of the projectile, as well as the mechanical properties of the target (in the case of concrete this depends on compression strength and ductility).

The risk of "scabbing", in a general manner, can be shown as a function of the depth reached by the projectile in its penetration as $x$, and the thickness of the target as e. In $\mathrm{HC}$ with $40 \mathrm{~kg} / \mathrm{m}^{3}$ of fibres, the risk of "scabbing" is high when the depth reached by the projectile equals or exceeds $45 \%$ of the target thickness, reaching 60 or $65 \%$ when fibre content is equal or greater than $60 \mathrm{~kg} / \mathrm{m}^{3}$ (6-8). In the HAR used in this work this value can be estimated, according to the results of penetration tests, at $75 \%$ for fibres of $40 \mathrm{~kg} / \mathrm{m}^{3}$, reaching $80 \%$ for content in excess of $60 \mathrm{~kg} / \mathrm{m}^{3}$.

To determine the thickness that a plate-target must have to absorb the impact energy of a projectile, examination of the amount of energy absorbed by it can be carried out in agreement with the aforementioned expression (and supported by the variables shown in Table 3). In the two examples that feature below, the process to be followed is shown. In the case of a target of concrete designated as HAR-10/40/1, subjected to strikes from $12.70 \mathrm{~mm}$ calibre projectiles, with a mass of $m=25 \mathrm{~g}$, impact velocity of $v_{i}=912 \mathrm{~m} / \mathrm{s}$, as shown previously, exit velocity after perforation $v_{s}=228 \mathrm{~m} / \mathrm{s}$, and given that the mass of the projectile hardly varies during perforation, the impact and exit kinetic energies would be respectively $E_{i}=10.40 \mathrm{~kJ}$ and $E_{s}=0.65 \mathrm{~kJ}$, which would mean that the energy absorbed by the plate would be $\Delta E=9.75 \mathrm{~kJ}$, and the braking factor $K$, or energy absorbed per centimetre of thickness of the plate, giving $\Delta E / e=9.75 / 10=0,97 \mathrm{~kJ} / \mathrm{cm}$; the $K$ value determined is within the range of those obtained by Moreno and Cánovas in a previous paper (7). Accordingly, the projectile will penetrate to a depth of $x=10.40 \mathrm{~kJ} / 0.97 \mathrm{~kJ} / \mathrm{cm}=10.72 \mathrm{~cm}$, and if "scabbing" occurs when the relationship between the depth reached by the projectile and the thickness of the target is of $x / e \leq 0.75$, as mentioned previously, the thickness required to avoid "scabbing" would be one of $12.72 / 0.75=14.3 \mathrm{~cm}$ (if the target has a thickness of $15 \mathrm{~cm}$ it will not see either perforation or "scabbing", as 
resultados obtenidos que se muestran en la Tabla 4. Razonando de igual forma con el hormigón HAR-10/60/1, se observa que el factor de frenado $K$ es en este caso ligeramente superior al anterior por el hecho de tener el hormigón mayor contenido de fibras, con un valor de $1,03 \mathrm{~kJ} / \mathrm{cm}$, lo que permite deducir el espesor necesario para frenar este proyectil que sería de $13,2 \mathrm{~cm} \mathrm{y,} \mathrm{por}$ consiguiente, también será frenado por un blanco de $15 \mathrm{~cm}$ de espesor.

Para un hormigón designado por HAR-25/40/1 sometido al impacto de un proyectil de $20 \mathrm{~mm}$ con una masa $m=$ $72 \mathrm{~g}$, la Tabla 4 indica que su velocidad $v i=1.254 \mathrm{~m} / \mathrm{s}$, mientras que la de salida, indicada en el apartado anterior, es vs $=105 \mathrm{~m} / \mathrm{s}$. Las energías cinéticas de impacto y salida del proyectil son, respectivamente: $E_{i}=56,61 \mathrm{~kJ}$ y $E_{S}=0,40 \mathrm{~kJ}$, con lo cual el factor de frenado del blanco es: $\Delta E / e=56,21 / 25=2,25 \mathrm{~kJ} / \mathrm{cm}$. El proyectil penetrará hasta una profundidad de $x=56,61 / 2,25=25,16 \mathrm{~cm}$. Si el "scabbing", en este caso, se produce cuando $x / e \leq 0,80$, como se ha indicado anteriormente, el espesor necesario para que no se produzca perforación ni "scabbing" será de $31,4 \mathrm{~cm}$, con lo cual un blanco de $35 \mathrm{~cm}$ frenará al proyectil. En el caso del $\mathrm{HC}$, el valor de $x / e$ es igual o inferior a 0,60 , por lo que se precisará un espesor mínimo de $42 \mathrm{~cm}$ para frenar el proyectil $y$, por tanto, los blancos de 35 y $40 \mathrm{~cm}$ se perforan, como así ha ocurrido en los ensayos realizados.

\section{CONCLUSIONES}

En los ensayos realizados se ha podido comprobar que el hormigón es un buen material de blindaje, especialmente si su resistencia a compresión es alta, pero al aumentar la resistencia el hormigón se hace cada vez más frágil, por lo que es preciso incrementar su ductilidad, lo que se consigue con la incorporación de fibras de acero. En la Figura 5 se observa el comportamiento dúctil de una placa de hormigón de $40 \mathrm{~cm}$ de espesor con $40 \mathrm{~kg} / \mathrm{m}^{3}$ de fibras de acero, que permanece integra con el orificio de entrada del proyectil y el "spalling" correspondiente, y en la Figura 6 se observa el comportamiento frágil de una placa de igual espesor sin fibras en la que toda la placa está fracturada. Por otra parte, el aumento de la tenacidad ha quedado puesto de manifiesto en los resultados de los índices de tenacidad y de punzonamiento dando lugar a que la profundidad de penetración de los proyectiles sea decreciente cuando aumenta el contenido de fibras en un mismo hormigón.

La influencia positiva de la resistencia a compresión del hormigón en el frenado de proyectiles se pone de manifiesto especialmente en las placas de $40 \mathrm{~cm}$ de espesor en las que se observa cómo para hormigones con la misma cuantía de fibras de acero los hormigones de $80 \mathrm{MPa}$ the results shown Table 4 reveal). If an HAR-10/60/1 concrete is considered in an equal way, it is observed that the braking factor is in this case slightly greater than the previous one, given the higher fibre content of this concrete, with a value of $1.03 \mathrm{~kJ} 7 \mathrm{~cm}$, and that the thickness necessary to brake a projectile can be deduced as $13.2 \mathrm{~cm}$ and, consequently, a plate-target of $15 \mathrm{~cm}$ of thickness too.

For an HAR-25/40/1 concrete submitted to a strike by a projectile of $20 \mathrm{~mm}$ with a mass of $m=72 \mathrm{~g}$, Table 4 shows that velocity of impact is $v_{i}=1254 \mathrm{~m} / \mathrm{s}$, and that of exit, indicated in the previous paragraph 2.2, of $v_{s}=$ $105 \mathrm{~m} / \mathrm{s}$. The kinetic energies of impact and exit of the projectile are respectively $E_{i}=56.61 \mathrm{~kJ}$ and $E_{s}=0.40 \mathrm{~kJ}$, and the braking factor $K=\Delta E / e=56.21 / 25=2.25 \mathrm{~kJ} / \mathrm{cm}$. The projectile will penetrate to a depth of $x=56.61 / 2.25=$ $25.16 \mathrm{~cm}$. If "scabbing" occurs when $x / e \leq 0.80$, as previously indicated, the necessary thickness required to prevent perforation and "scabbing" should would be $31.4 \mathrm{~cm}$, which would reveal a plate-target of $35 \mathrm{~cm}$ as that which would brake the progress of the projectile. In the case of the $\mathrm{HC}$, the value of $\mathrm{x} / \mathrm{e}$ would be equal to or lower than 0.60 , by which the plate-target would require a minimum thickness of $42 \mathrm{~cm}$ to stop the projectile, meaning that those with thicknesses of $35 \mathrm{~cm}$ and $40 \mathrm{~cm}$ would be perforated, as happened in the tests performed.

\section{CONCLUSIONS}

The tests carried out have allowed verification that concrete is a good shielding material, especially if its compression strength is high. However, as increasing strength makes concrete increasingly fragile it is necessary to increase ductility by adding steel fibres. Figure 5 shows the ductile behaviour of a plate-target made from concrete with a thickness $40 \mathrm{~cm}$ and with $40 \mathrm{~kg} / \mathrm{m}^{3}$ of steel fibres, illustrating the entrance crater and corresponding "spalling"; and Figure 6 reveals the fragile behaviour of a plate of equal thickness without fibres in which the entire plate is fractured. Conversely, the increase in toughness is shown in the results of the toughness and shear failure indices, leading to the depth of penetration of the projectiles diminishing when fibre content is increased in a given concrete.

The positive influence of the compression strength of concrete in the braking of projectiles is revealed, in particular, in plates of $40 \mathrm{~cm}$ of thickness. In such as case this is noted in those with matching quantities of steel fibres, those of $80 \mathrm{MPa}$ that are not perforated by $20 \mathrm{~mm}$ 


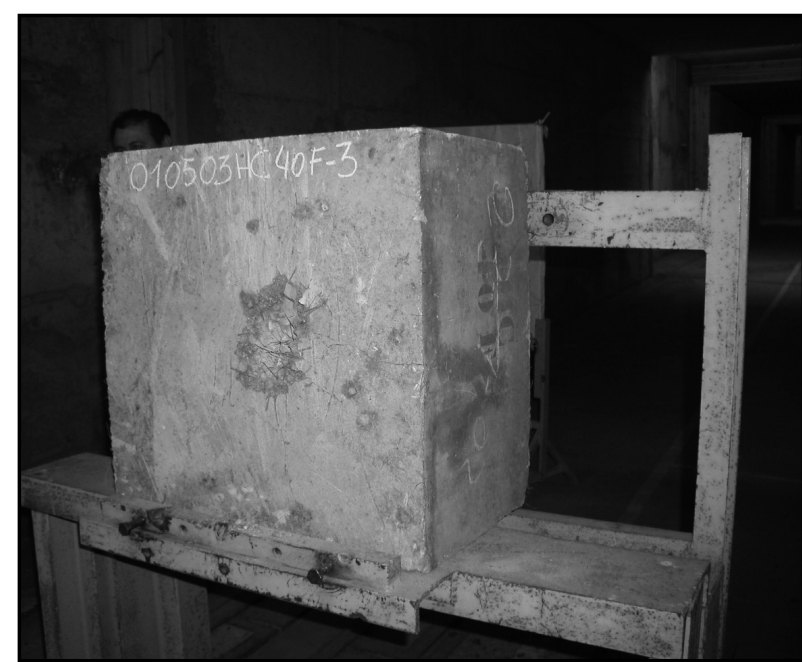

Figura 5. Impacto de proyectil de $25 \mathrm{~mm}$ APDS en placa-blanco de $40 \mathrm{~mm}$ de espesor de hormigón con fibras de acero (dúctil). Figure 5. Impact of $25 \mathrm{~mm}$ APDS projectile in a concrete with steel fibers plate-target of $40 \mathrm{~mm}$ thickness (ductile).

no son perforados con proyectiles de calibre $20 \mathrm{~mm}$ y $25 \mathrm{~mm}$ y, sin embargo, sí lo son los hormigones de $30 \mathrm{MPa}$ de resistencia.

El "spalling" se produce en todos los casos en que incide un proyectil sobre el blanco de hormigón, dependiendo su volumen de las características del hormigón, de la velocidad y calibre del proyectil, siendo para igual calibre, velocidad y cuantía de fibras el volumen mayor en los HAR que en los HC. En todos los casos la profundidad del cráter es reducida.

El "scabbing" se produce cuando el proyectil perfora el blanco o cuando penetrando en él llega a una distancia determinada del trasdós del mismo. En general, para un mismo blanco, el "scabbing" presenta mayor volumen que el "spalling" presentando tendencia a ser de inferior volumen cuando el contenido de fibras es más elevado.

Conviene indicar que los fenómenos que se producen en la penetración de un proyectil son complejos, debido a ser el hormigón un material heterogéneo, en el que además puede haber un reparto no del todo uniforme de las fibras en su masa, la velocidad de impacto puede ser diferente, etc., lo que lleva a considerar que no hay un valor fijo umbral tanto de formación de "scabbing" como de límite de perforación sino que éste oscila entre determinados valores y que, por tanto, como en todos los fenómenos complejos, el riesgo está condicionado a lo ajustado que sean los coeficientes de seguridad empleados en el diseño de los blancos.

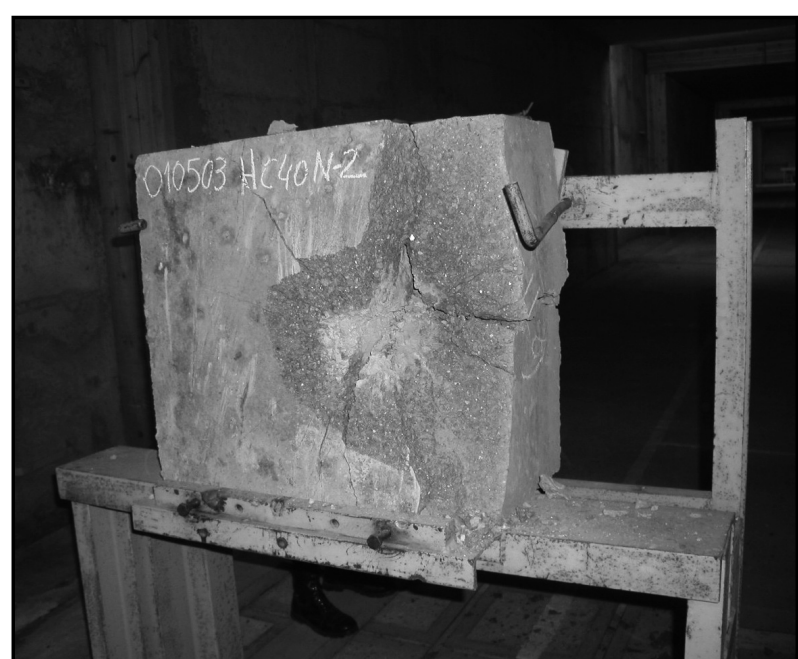

Figura 6. Impacto de proyectil de $25 \mathrm{~mm}$ APDS en placa-blanco de $40 \mathrm{~mm}$ de espesor de hormigón sin fibras de acero (frágil).

Figure 6. Impact of $25 \mathrm{~mm}$ APDS projectile in a concrete without steel fibers plate-target of $40 \mathrm{~mm}$ thickness (fragile).

and $25 \mathrm{~mm}$ projectiles (though they are concretes of $30 \mathrm{MPa}$ ).

"Spalling" occurs on all occasions when a projectile strikes a concrete target, with the volume of the crater depending on the characteristics of the concrete, and velocity and calibre of the projectile, with the calibre and velocity of the projectile, as well as the quantity of fibres, being greater in the HAR than the HC. In all the cases the depth of the crater was low.

"Scabbing" occurs either when the projectile perforates the plate-target or when it reaches a certain point within the surface. In general, for the same plate "scabbing" is of a greater magnitude than spalling, with it being of a lesser size when fibre content is higher.

It should be noted that the phenomena that arise when a projectile penetrates a target are complex, given that concrete is a heterogeneous material, in which there can be an inconsistent distribution of fibres in its mass, and that the velocity of projectile impact can vary from one case to another, amongst many others. This leads to consideration that a fixed threshold value is inexistent, either in the formation of "scabbing" or the limit of perforation, but that they oscillate among certain values (as in the cases of all complex phenomena) and that risk is influenced by the safety coefficients used in the design of targets. 


\section{BIBILIGRAFÍA / BIBLIOGRAPHY}

(1) Melián, G.; Barluenga, G.; Hernández-Olivares, F.: "Toughness increase of self compacting concrete reinforced with polypropylene short fibers", Mater. Construcc., vol. 60, no 300 (2010), pp. 83-97.

(2) Ho Kuet Qeun: "Effects of concrete properties on the protective capability of concrete targets in withstanding small arms fire", Msc. Project Report, The Royal Military College of Science (RMCS) (nov., 1988), Shrivenham (Reino Unido).

(3) Gutiérrez Pamies, R.: "Predicción de los efectos inertes del impacto directo de proyectiles y bombas", Memorial de Ingeniería de Armamento, no 126 (1992), Madrid (España).

(4) Gutiérrez Pamies, R.: "Fórmulas modernas para la predicción de la penetración y la perforación de proyectiles en el hormigón", Memorial de Ingeniería de Armamento, no 130 (1993), Madrid (España).

(5) Amstrong, P.: "Projectile penetration into fibre reinforced concrete", Ph. D. Thesis, University of Sheffielf. Dpt. Of Civil and Structural Engineering (1987), Sheffielf (Reino Unido).

(6) Moreno Almansa, E.: "Evaluación de la resistencia al impacto de proyectiles de armas ligeras sobre hormigón convencional y reforzado con fibras metálicas", tesis doctoral (1995), ETS de Ingenieros de Caminos, Canales y Puertos, Universidad Politécnica de Madrid. (7) Moreno Almansa, E.; Fernández Cánovas, M.: "Discusión del impacto de proyectiles de pequeño calibre en hormigón. Exposición de un modelo de cálculo y diseño", ASINTO, no 183-184 (2000), pp. 42-54, Madrid (España).

(8) Moreno Almansa, E.; Fernández Cánovas, M.: "Behaviour of normal and steel fibre reinforced concrete under impact of small projectiles", Cement and Concrete Research, 28 (1999), pp. 1807-1814. http://dx.doi.org/10.1016/S0008-8846(99)00174-X 
Materiales de Construcción

Vol. 64, Issue 316, October-December 2014, err001

ISSN-L: 0465-2746

\section{Erratum}

Volume 62, Issue 307, July-September 2012:

The manuscript:

Cánovas, M.F.; Hernando, V.M. (2012) Comportamiento de hormigones de alta resistencia reforzados con fibras de acero frente al impacto de proyectiles/Behavior of steel fiber high strength concrete under impact of projectiles. http://dx.doi.org/10.3989/mc.2012.00911.

Correct data is as follows:

Cánovas, M.F.; Gaitan, V.H. (2012) Comportamiento de hormigones de alta resistencia reforzados con fibras de acero frente al impacto de proyectiles/Behavior of steel fiber high strength concrete under impact of projectiles. http://dx.doi.org/10.3989/mc.2012.00911.

Copyright: ( 12014 CSIC. This is an open-access article distributed under the terms of the Creative Commons Attribution-Non Commercial (by-nc) Spain 3.0 Licence. 